
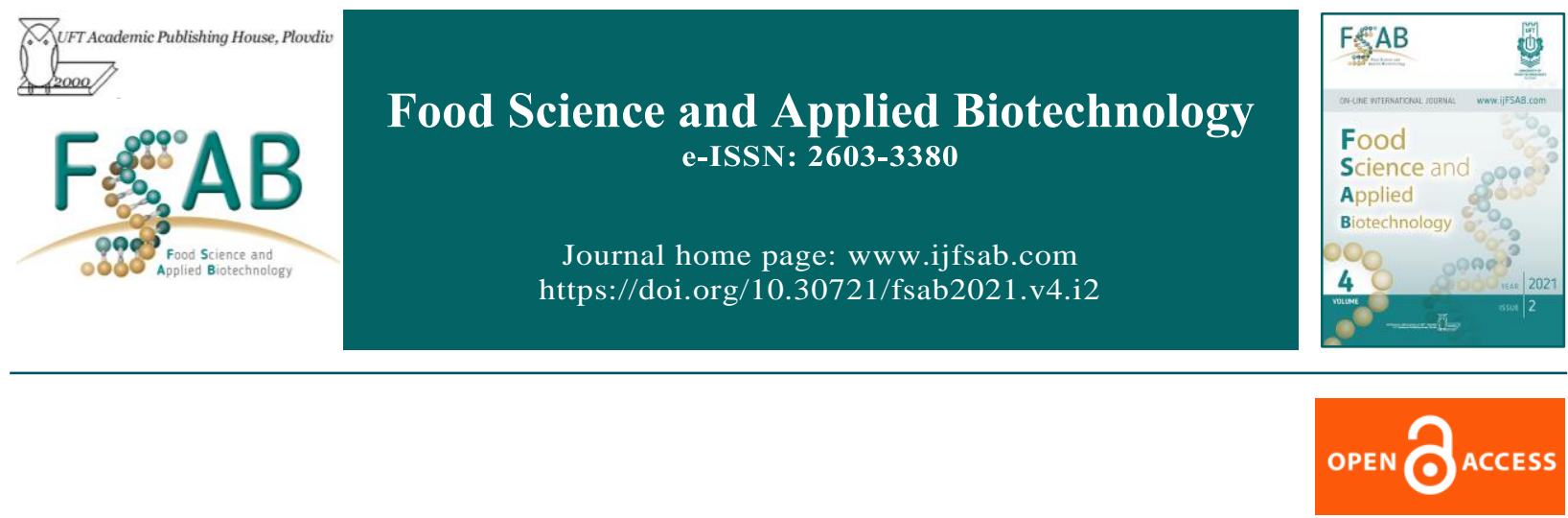

Research Article

\title{
Development and evaluation of low-fat ready-made dishes prepared by the sous vide process from hybrid sorubim fillets by using different treatments
}

\author{
Angela Dulce Cavenaghi Altemio ${ }^{1}$, Tais Cardoso da Silva ${ }^{1}$, Thais Cardoso Merlo ${ }^{1}$, Gustavo \\ Graciano Fonseca ${ }^{2 \square}$ \\ ${ }^{1}$ Faculty of Engineering, Federal University of Grande Dourados, Dourados, Brazil \\ ${ }^{2}$ Faculty of Biological and Environmental Sciences, Federal University of Grande Dourados, Dourados, Brazil
}

\begin{abstract}
The aim of this work was to develop and evaluate ready-made dishes of hybrid sorubim fish fillets obtained by the sous vide process. Three treatments were investigated: T1 with brine containing fine-herbs, T2 with brine containing fine-herbs, olive oil, and rosemary; and T3 with the same brine as in T1 but added of $30 \%$ of tomato sauce. Results showed the protein content increased according to the type of liquid medium employed, where the lowest value was determined for $\mathrm{T} 1$ and the highest value for $\mathrm{T} 3$. The sous vide process did not influence the lipid and protein contents of the treatments, be by the addition of olive oil (T2) nor by tomato sauce (T3). Treatments differed for all sensory attributes and presented acceptability indexes above $78.66 \%$. indicating that they are good alternatives for fish consumption. However, T1 had the highest percentage of purchase intention (97.23\%), representing the best product for commercialization.
\end{abstract}

Keywords: fish product, ready-to-eat, ready-to-cook, sensory analysis, acceptability, protein

Abbreviations: AI - acceptation index, ANOVA - analysis of variance, CFU - counting forming units, ECL - Equivalent Chain Length, FAME - fatty acids methyl esters, P - Probability, PUFA - polyunsaturated fatty acids, T1 - treatment 1, T1 - treatment 2, T3 - treatment 3

${ }^{\square}$ Corresponding author: Gustavo Graciano Fonseca, Laboratory of Bioengineering, Faculty of Biological and Environmental Sciences, Federal University of Grande Dourados, Rodovia Dourados-Itahum, km 12, Dourados, Brazil, tel.: +55 (67) 34102027; E-mail: ggf@ufgd.edu.br

Article history:

Received 18 June 2021

Reviewed 1 July 2021

Accepted 18 August 2021

Available on-line 10 October 2021

https://doi.org/10.30721/fsab2021.v4.i2.147 (C) 2021 The Authors. UFT Academic publishing house, Plovdiv 


\section{Introduction}

In recent years, the food industry has launched several new products. It resulted from factors such as technological development, growth in external competition, and consumer's demand, which incorporated new values into their preferences (Honma et al. 2020). Due to the immense range of products offered on the market, consumers tend to become more selective, aiming for new and quality products. In this context, the fish industry needs to innovate and develop products that meet and surprise the consumers to gain visibility and a market ahead of the competition (Gonçalves et al. 2009).

Fish meats present high levels of unsaturated fatty acids, which brings benefits to human health. They are rich in amino acids, vitamins and minerals, making them a nutritious food source (Can et al. 2015). The reduction in natural stocks of fish has been driving production in captivity.

The hybrid sorubim is a fish of highlighted commercial and economic value. The great productive potential, i.e. rapid growth and efficient feed conversion, and the quality of the meat (with pattern for exportation) are what arouses the interest for its production and industrial exploration (Crepaldi et al. 2006). The hygienic fish processing enables their safe commercialization by ensuring the quality and shelf-life of the fish products (Soccol and Oetterer 2003).

The change in the nutritional profile of the population and in the supply of quality fish in the domestic market can direct the consumption into new food products that are not in the traditional canned form or simple fillet. In Brazil, the offer of fish to the consumer is based mainly on the fresh form, consisting on the offer of few species (Lopes et al. 2016). There are also some chilled and frozen cuts on the market, but it is possible to obtain new products from separated meat, requiring, however, more complex technology and greater investment (Palmeira et al. 2016).

There are several options that the modern consumers have to reduce impact on the lack of time on their daily lives, and to increase their convenience to facilitate the domestic routine. One of the most interesting is the food with ready-made dishes, which can be stored for a relatively long time and prepared quickly, even by those who have no culinary skills (Palmeira et al., 2016; Husein et al. 2020). Ready-made food are industrialized products elaborated totally or partially, which contains meat of different species, prepared in isolation or combined with ingredients, such as: sauces, vegetables, flour, cereals and others, subjected to an appropriate technological process (MAPA,2001).

Among the various technologies for preparing ready-made products is the sous vide technique. Barbosa-Cánovas et al. (2005) refer to the term sous vide as the method of cooking fresh food in vacuum sealed plastic packaging at low temperatures for a long period of time. After cooking, the food can be stored or supplemented with some other ingredient and will be ready to serve. The vacuum prevents the rancidity caused by lipid oxidation, as well as the degradation of the food by aerobic microorganisms. In addition, the process of keeping a food under vacuum allows the preservation of aspects such as freshness, color, flavor, nutritional content, moisture and appearance from preparation to consumption (Vaudagna et al. 2002).

Thus, the aim of this work was to develop and evaluate ready-made dishes obtained by the sous vide process from hybrid sorubim fillets.

\section{Materials and Methods}

Fillets of hybrid sorubim. Dot and comma hybrid sorubim (Pseudoplatystoma reticulatum $\mathrm{x}$ Pseudoplatystoma corruscans) fishes with 8 months age and average weight of $1.750 \pm 0.050 \mathrm{~kg}$ were obtained from a local fish farm. They were transported to the Laboratory of Food Technology from the Federal University of Grande Dourados, Dourados, MS, Brazil, where they were stunned by thermonarcosis in a mixture of ice and water $(1: 1)$ to bleed out, gutted, washed with 5 ppm chlorinated water spray, and filleted, under refrigerated conditions $\left(12^{\circ} \mathrm{C}\right)$. Fillets were immediately utilized for the analytical determinations, except for the sensory analysis. For this later, fillets were packaged in sterilized 5-layer nylon propylene bags and stored up to one week under freezing prior the analyses.

Ready-made dishes of hybrid sorubim fillets prepared by the sous vide process. Three treatments were prepared by the sous vide process 
from the hybrid sorubim fillets. The differences were that in Treatment 1 (T1) it was added brine containing fine-herbs consisting of equal amounts of chopped fresh parsley, chives, tarragon and chervil (control); in Treatment 2 (T2) it was added brine containing fine-herbs plus olive oil (20\%) and rosemary $(0.4 \%)$; and in Treatment 3 (T3) it was added the same brine as in $\mathrm{T} 1$ and after the marination time, when packed, it received $30 \%$ of industrialized tomato sauce in relation to the weight of the fillets. All treatments were marinated by immersion using the brine $(1: 1)$ as shown in Table 1. After marination, the treated fillets were placed in the nylon-poly carton, without addition of liquid medium, sealed under vacuum and subjected to the pasteurization process in a sous vide thermocirculator with ultrasound (Cetro, Model Constantine (Bauri, SP). The average thickness of the fillets was of $20 \mathrm{~mm}$, and the pasteurization time of $41 \mathrm{~min}$. After reached the internal temperature of $60.5^{\circ} \mathrm{C}$ by the pasteurization process (Embarek and Huss 1993), the treated fillets were immersed in ice water to be cooled during $18 \mathrm{~min}$. up to reach the internal temperature of $5^{\circ} \mathrm{C}$ (Table 3 ). Then treated fillets were stored at $-18^{\circ} \mathrm{C}$.

The vacuum packaging (nylon-poly) was supplied by Cryovac do Brasil Ltda (São Paulo, SP). The tomato sauce and the spices were purchased in the local commerce (Dourados, MS).

Chemical analysis. Moisture, crude protein, crude ash, and etheric extract contents of the hybrid sorubim fillets were determined in triplicate according to the methods described by AOAC (2012). Moisture was determined by the oven drying method at $105^{\circ} \mathrm{C}$ until constant weight (method 950.46), protein by the Kjeldhal method (method 928.08), ether extract (crude fat) by the extraction technique using a Soxhlet apparatus (method 991.36) and ash by using the muffle oven technique (method 920.153). The $\omega-3$ and $\omega-6$ fatty acid methyl esters (FAME) of hybrid sorubim fillets were identified using a gas chromatograph (Varian, model AA 3800), equipped with flame ionization detector and a SIL-8 capillary column of fused silica (30 m length $x 0.25 \mathrm{~mm}$ internal diameter $\mathrm{x} 0.25 \mu \mathrm{m}$ thickness), using $\mathrm{H}_{2}$ as entrainment gas at a split ratio of $1: 10(30 \mathrm{~mL} / \mathrm{min} .: 300 \mathrm{~mL} / \mathrm{min}$.). The analyses were performed at a starting temperature of $165^{\circ} \mathrm{C}$, which was maintained for $18 \mathrm{~min}$., then a heating rate of $4^{\circ} \mathrm{C} / \mathrm{min}$. was applied up to $235^{\circ} \mathrm{C}$, and then maintained for $25 \mathrm{~min}$. The detector and injector temperatures were $220^{\circ} \mathrm{C}$ and $240^{\circ} \mathrm{C}$, respectively. Gas chromatographic analysis was performed in duplicate. The samples were esterified following the guidelines of the ISO 5509 standard (ISO 2000) and the volume injected was of $1.0 \mu \mathrm{L}$, at a split ratio of 1:80.

The FAME were identified by comparing the retention time of the constituents of the sample with a mixture of $\omega-3$ and $\omega-6$ fatty acid methyl ester standards (Supelco) and ECL (Equivalent Chain Length) values from the corrected sample retention times. Concentrations were determined by integrating peak areas with Varian Workstation Star software, version 5.0. The results were expressed in percentage by mass of $\omega-3$ and $\omega-6$ in relation to the total mass of esters of the total fatty acids present in the sample.

The biological effect of the essential fatty acids was determined by the quotient of the omega- 6 and the omega-3 fatty acids (Simopoulos 2002).

Microbiological analysis. Microbiological analyses of the hybrid sorubim filets in natura or processed by the sous vide method were carried out for Salmonella sp., coagulase positive staphylococci, and thermo-tolerant coliforms at $45^{\circ} \mathrm{C}$ to ensure food safety of the judges during sensory analysis, in accordance with the methodology described elsewhere (USDA/FSIS 1998).

Sensory analysis. Sensory analyses of the readymade dishes elaborated with fillets of hybrid sorubim by the sous vide process were conducted in 2019 by 50 trained panelists, consumers of fish, with ages from 20 to 51 years old. A vertical structured nine-point hedonic scale of mixed category ( $9=$ like extremely; $1=$ dislike extremely) was used for evaluation of the attributes colour, odor, tenderness, and taste. Samples were cut with edges of approximately $10 \times 10 \times 20 \mathrm{~mm}$, stored in styrofoam box coated with aluminium foil for temperature maintenance and presented in monadic form, randomly coded with three digits. 
Table 1. Formulations utilized for the ready-made dishes of hybrid sorubim fillets obtained by the sous vide process

\begin{tabular}{cccc}
\hline Ingredient & \multicolumn{3}{c}{ Treatment formulation, \% } \\
\cline { 2 - 4 } & T1 & T2 & T3 \\
\hline Water & 95.4 & 75.0 & 95.4 \\
Refined sodium chloride & 3.2 & 3.2 & 3.2 \\
Citric acid & 0.4 & 0.4 & 0.4 \\
Dehydrated garlic & 0.4 & 0.4 & 0.4 \\
Fine herbs & 0.4 & 0.4 & 0.4 \\
White pepper & 0.2 & 0.2 & 0.2 \\
Rosemary & - & 0.4 & - \\
Olive oil & - & 20.0 & - \\
Tomato sauce & & & $30.0^{*}$
\end{tabular}

* In addition to the total fillet weight. T1= (control) hybrid sorubim fillets; $\mathrm{T} 2=$ hybrid sorubim fillets with rosemary and olive oil; T3= hybrid sorubim fillets with tomato sauce. Tomato sauce was prepared with tomato, sugar, onion, garlic, modified starch, oregano, parsley, basil, and monosodium glutamate ( $6.8 \mathrm{~g} / 100 \mathrm{~g}$ carbohydrates, $1.0 \mathrm{~g} / 100 \mathrm{~g}$ protein, $1.8 \mathrm{~g} / 100 \mathrm{~g}$ fibre, and $0.2 \mathrm{~g} / 100 \mathrm{~g}$ salts).

In the same sheet, it was evaluated the purchase intention using a 5-point scale, where $5=$ certainly would purchase, 4 = probably would purchase, $3=$ perhaps would purchase / perhaps would not purchase, $2=$ probably would not purchase and $1=$ certainly would not purchase, which was expressed as the percentage of total score (Cavenaghi-Altemio et al. 2018). For frequency of consumption of commercial tomato sauces, a 5-point scale was utilized, where $5=$ weekly, $4=2$ to 4 times a week, $3=$ fortnightly, $2=$ monthly, and $1=$ rarely. The acceptation index (AI) was calculated according to the Eq. 1. The sample was considered accepted if the value was greater than $70 \%$ (Stone and Sidel 2004).

A. $I=\frac{\text { average of the attributed grades }}{\text { maximum attributed grade }} \times 100$

Statistical analysis. Statistical results were evaluated through analysis of variance (ANOVA) and the Tukey test for comparison of means, at a level of $5 \%$ of significance, using the statistical software Statistica 8.0 (STATISTICA, 2007). The sensory attributes, and the purchase intention results were presented in percentage.

\section{Results and Discussion}

Chemical analysis. Table 2 presents the results of the means and standard deviations of the proximate composition of ready-made dishes prepared by the sous vide process from hybrid sorubim fillets by using different treatments.

The moisture and ash contents did not show a significant difference between treatments at the level of $5 \%$. The moisture content varied from $74.94 \%$ in $\mathrm{T} 3$ to $77.00 \%$ in $\mathrm{T} 1$, while the ash content varied from $1.61 \%$ in $\mathrm{T} 3$ to $2.01 \%$ in $\mathrm{T} 1$ (Table 2). Ramos Filho et al. (2008) evaluated the proximate composition of spotted sorubim ( $P$. corruscans) fillets and found an average moisture value of $77.26 \%$, a value slightly superior to those found for the treatments carried out here, and an ash content of $1.01 \%$, a value slightly inferior to those obtained here (Table 2). Frascá-Scorvo et al. (2008) reported $74.06 \%$ moisture and $1.22 \%$ ash for fillets obtained from the same fish species. These differences may be related to the addition of ingredients in the preparation of the ready-made dishes. For proteins 
Food Science and Applied Biotechnology, 2021, 4(2), 138-146

Table 2. Proximate composition of the dishes of hybrid sorubim fillets obtained by the sous vide process

\begin{tabular}{ccccc}
\hline \multirow{2}{*}{ Treatment } & \multicolumn{4}{c}{ Proximate composition, \% } \\
\cline { 2 - 5 } & Moisture & Protein & Lipids & Ash \\
\hline T1 & $77.00 \pm 2.41$ & $18.00^{\mathrm{a}} \pm 0.01$ & $3.00^{\mathrm{a}} \pm 0.01$ & $2.01 \pm 0.09$ \\
T2 & $75.45 \pm 0.59$ & $18.35^{\mathrm{b}} \pm 0.05$ & $3.65^{\mathrm{b}} \pm 0.01$ & $1.69 \pm 0.92$ \\
T3 & $74.94 \pm 0.05$ & $19.79^{\mathrm{c}} \pm 0.02$ & $3.48^{\mathrm{c}} \pm 0.01$ & $1.61 \pm 0.84$ \\
P & 0.26 & 0.00 & 0.00 & 0.79
\end{tabular}

Means with the same letter in the same column do not differ statistically at 5\% (P>0.05). P: Probability. Treatments (T1, T2, and T3) according to Table 1.

and lipids, a significant difference between treatments was observed at the level of $5 \%$ (Table 2). The protein content increased according to the type of liquid medium employed, where the lowest value was determined for $\mathrm{T} 1$ and the highest value for T3. Ramos Filho et al. (2008) and Frascá-Scorvo et al. (2008) found $17.90 \%$ and $19.28 \%$ protein, respectively, for spotted sorubim fillets, a values close to the range (18.00-19.79\%) obtained for the treatments (Table 2). The lipids varied in a range (3.00-3.65\%; Table 2) that matches with the 3.30\% lipids reported for spotted sorubim (Ramos Filho et al. 2008). However, other authors reported a higher content of $4.85 \%$ lipids for fillets obtained from the same species. Thus, it is clear that beyond the differences between treatments, it must be considered that the fish composition is very variable even for the same species. These variations found in fillets' composition may be related to age, body region, sexual cycle, and diet of the fish (Cavenaghi-Altemio et al. 2020). Surprisingly, the sous vide process did not influence the lipid and protein contents of the treatments, be by the addition of olive oil (T2) nor by tomato sauce (T3), respectively. According to Sigurgisladottir et al. (2000), the lipid and protein contents in smoked fish are higher than in fresh fish due to the dehydration of the fish by smoking process, which causes concentrating of the other constituents. Here, during sous vide processing, there was no excessive loss of moisture and the constituents practically remained at same concentration of the raw hybrid sorubim.

The mass percentage of the fatty acids omega 3 and 6 in relation to the total fatty acid methyl esters
(FAME) present in the samples are shown in Table 3 . The samples of hybrid sorubim fillets presented relatively lower levels than that reported elsewhere for spotted sorubim fillets, which obtained total contents of omega 3 and omega 6 around $8.90 \%$ and $8.43 \%$, respectively (Ramos Filho et al. 2008). Most of the freshwater fish are excellent sources of $\omega-3$ polyunsaturated fatty acids (PUFA), ranging from $2.95 \%$ to $27.44 \%$ (Suárez-Mahecha et al. 2002). However, the contents found here were below these values (Table 3). The low amount of omega 3 and 6 present in the hybrid sorubim fillets may be related to the breeding method. As they are fish raised in captivity, fed basically with commercial feed, have low levels of polyunsaturated fatty acids of the omega-3 series when compared to native species (Moreira et al. 2001).

The composition of omega-3 and omega- 6 fatty acids of the fillets prepared by the sous vide process (T1, T2, and T3) presented even lower values when compared to the raw fillet. This decrease possibly occurred due to the break of the double chains of the fatty acids during the cooking of the fillets.

The biological activity and effects of essential fatty acids on human health depends on the ratio of the omega- 6 and omega- 3 fatty acids. Values below to 4.0 in the diet are desirable for the prevention of cardiovascular diseases (Simopoulos 2002). From Table 3, it can be observed that all the ratios obtained were below 4.0, thus suggesting that these PUFA are in concentrations enough to prevent the risk of coronary heart diseases. 
Table 3. Fatty acids composition of the raw fillets and dishes of hybrid sorubim fillets obtained by the

\begin{tabular}{|c|c|c|c|}
\hline \multirow[t]{2}{*}{ Treatment } & \multicolumn{2}{|c|}{ Fatty acid, \% } & \multirow[t]{2}{*}{$\Omega-6 / 3$} \\
\hline & $\mathbf{\Omega - 3}$ & న-6 & \\
\hline Raw fish fillets & 1.52 & 2.63 & 1.73 \\
\hline $\mathrm{T} 1$ & 1.26 & 2.2 & 1.75 \\
\hline $\mathrm{T} 2$ & 1.2 & 2.18 & 1.82 \\
\hline $\mathrm{T} 3$ & 1.05 & 2.08 & 1.98 \\
\hline
\end{tabular}

Treatments (T1, T2, and T3) according to Table 1

Microbiological analysis. Coliforms at $45^{\circ} \mathrm{C}$, coagulase positive staphylococci, and Salmonella sp. were carried out of for the raw fish fillets and the treatments in order to guarantee the food security of judgers priori the conduction of the sensory analysis (Table 4).

Results obtained were within the limits established by Brazilian legislation, which recommends a maximum of $1.0 \times 10^{2} \mathrm{CFU} / \mathrm{g}$ for thermotolerant coliforms at $45^{\circ} \mathrm{C}$, a maximum of $5.0 \times 10^{2} \mathrm{CFU} / \mathrm{g}$ for coagulase positive staphylococci and the absence of Salmonella sp. in $25 \mathrm{~g}$ of sample (ANVISA 2001).

The absence of these microorganisms in fresh fish indicates that the cleaning and filleting processes were carried out properly, demonstrating that there were good hygiene procedures during processing, as it is normally transmitted by inadequate manipulation (Leira et al. 2019).

Table 4. Microbiological analyses of the raw fillets and dishes of hybrid sorubim fillets obtained by the sous vide process.

\begin{tabular}{cccc}
\hline Treatment & Coliforms at $\mathbf{4 5}^{\circ} \mathbf{C}$ & $\begin{array}{c}\text { Coagulase positive } \\
\text { staphylococci }\end{array}$ & Salmonella sp. \\
\hline Raw fish fillets & $<1.0 \times 10^{1} \mathrm{CFU} / \mathrm{g}$ & $<1.0 \times 10^{1} \mathrm{CFU} / \mathrm{g}$ & Absence in $25 \mathrm{~g}$ \\
$\mathrm{~T} 1$ & $<1.0 \times 10^{1} \mathrm{CFU} / \mathrm{g}$ & $<1.0 \times 10^{1} \mathrm{CFU} / \mathrm{g}$ & Absence in $25 \mathrm{~g}$ \\
$\mathrm{~T} 2$ & $<1.0 \times 10^{1} \mathrm{CFU} / \mathrm{g}$ & $<1.0 \times 10^{1} \mathrm{CFU} / \mathrm{g}$ & Absence in $25 \mathrm{~g}$ \\
$\mathrm{~T} 3$ & $<1.0 \times 10^{1} \mathrm{CFU} / \mathrm{g}$ & $<1.0 \times 10^{1} \mathrm{CFU} / \mathrm{g}$ & Absence in $25 \mathrm{~g}$ \\
\hline
\end{tabular}

CFU: counting forming units. Treatments (T1, T2, and T3) according to Table 1.

Sensory analysis. Table 5 shows the means and standard deviations of the scores of the sensory attributes (odor, color, flavor and softness) for the consumer acceptance test of the ready-made dishes prepared by the sous vide process from hybrid sorubim fillets. The average classification for all sensory attributes ranged varied from "I liked it moderately" to "I liked it a lot" (Table 5).

Treatments differed $(\mathrm{p}<0.05)$ for all sensory attributes (Table 5). Regarding to the odor and the color, T1 and T2 did not differ statistically from each other $(\mathrm{p}<0.05)$, but T3 differed from the other treatments, possibly due to the presence of tomato sauce, which makes the product more attractive especially to the color criterion. For the flavor and the tenderness, $\mathrm{T} 1$ did not differ statistically ( $\mathrm{p}$ $<0.05)$ from the other treatments, while T2 differed in both flavor and tenderness from T3. The treatment with tomato sauce (T3) obtained an average higher grade in the flavor when compared to the other treatments. In relation to the average scores for tenderness, T3 obtained a higher average 
than T2. All treatments presented acceptability indexes above $78.66 \%$ (Table 5). When the acceptability index is equal to or greater than $70 \%$, the product is considered accepted (Stone and Sidel 2004). Thus, all ready-made dishes prepared by the sous vide process from hybrid sorubim fillets would be accepted in relation to all sensory attributes evaluated. The presentation of the fish in a more elaborate way combined with the use of some natural spices may increase the shelf life and make the product more appreciated by consumers, stimulating its consumption (Santos et al. 2007), which probably occurred here.

Figure 1 shows the percentage of the purchase intention frequencies of the ready-made dishes. T1 had the highest percentage of purchase intention $(97.23 \%)$ for the sum "certainly would buy" and "probably buy", followed by T2 $(94.45 \%)$, and T3 $(80.56 \%)$. All treatments showed good rates of purchase intention, indicating that if they were on the market, they would present a good potential for commercialization.

Table 5. Sensory analysis of the dishes of hybrid sorubim fillets obtained by the sous vide process.

\begin{tabular}{ccccc}
\hline Treatment & Color & Odor & Taste & Tenderness \\
\hline T1 & $7.56^{\mathrm{b}} \pm 1.27(84.00)$ & $7.28^{\mathrm{b}} \pm 1.63(80.89)$ & $8.03^{\mathrm{ab}} \pm 0.97(89.22)$ & $7.94^{\mathrm{ab}} \pm 0.89(88.22)$ \\
$\mathrm{T} 2$ & $7.36^{\mathrm{b}} \pm 1.13(81.77)$ & $7.08^{\mathrm{b}} \pm 1.30(78.66)$ & $7.44^{\mathrm{b}} \pm 1.38(82.67)$ & $7.56^{\mathrm{b}} \pm 1.34(84.00)$ \\
$\mathrm{T} 3$ & $8.22^{\mathrm{a}} \pm 1.02(91.33)$ & $8.08^{\mathrm{a}} \pm 1.13(89.78)$ & $8.22^{\mathrm{a}} \pm 1.12(91.33)$ & $8.25^{\mathrm{a}} \pm 0.87(91.67)$ \\
$\mathrm{P}$ & 0.00 & 0.01 & 0.02 & 0.02
\end{tabular}

Means with the same letter in the same column do not differ statistically at 5\% (P>0.05). Values in parenthesis are referred to the acceptation index (\%). P: Probability. Treatments (T1, T2, and T3) according to Table 1.

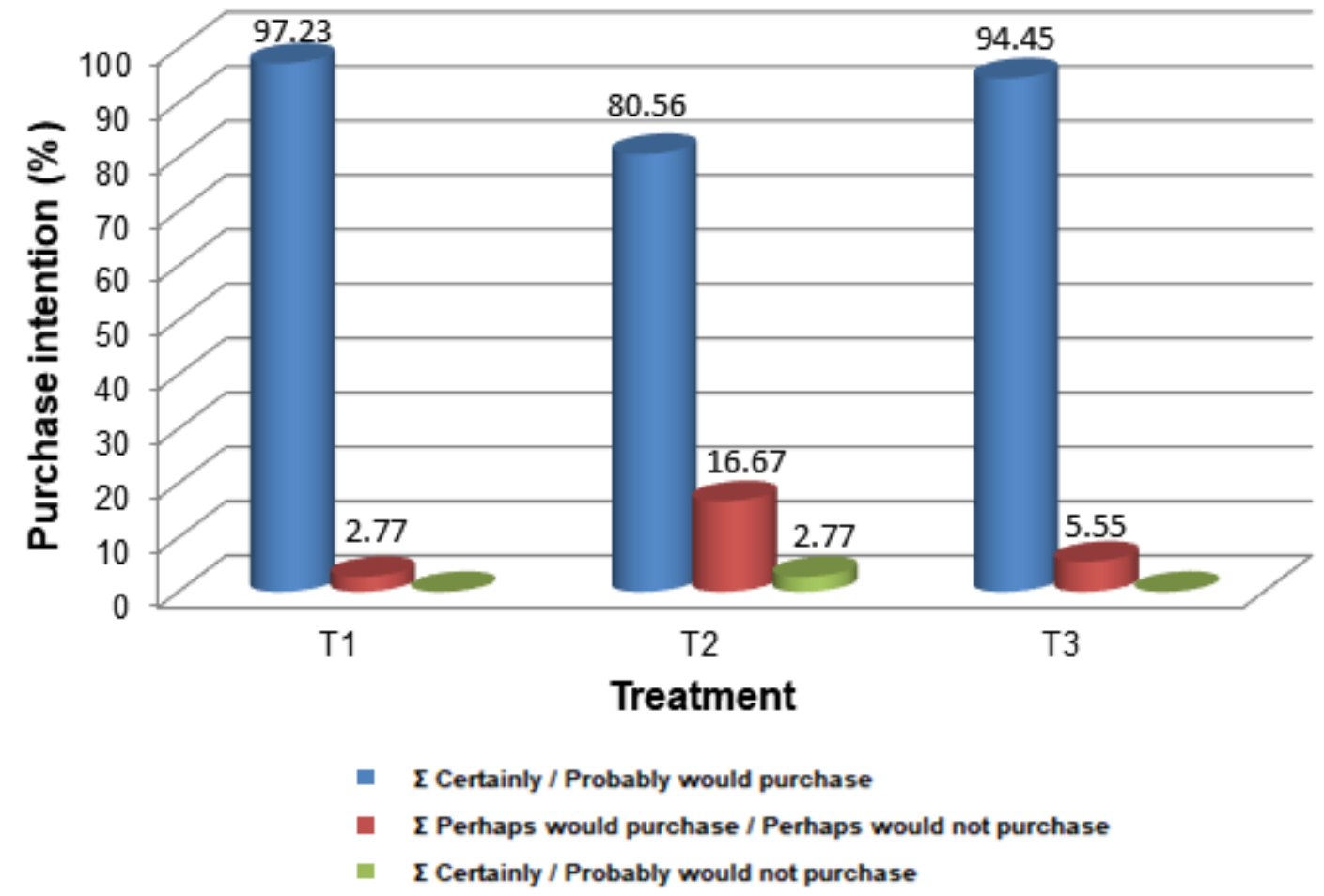

Figure 1. Purchase intention (\%) of ready-made dishes prepared by the sous vide process from hybrid sorubim fillets by using different treatments. Treatments (T1, T2, and T3) according to Table 1. 


\section{Conclusions}

Ready-made dishes prepared by the sous vide process from hybrid sorubim fillets were found according to the microbiological standards established by Brazilian legislation. Proximate composition and sensory analysis (consumer acceptance test, acceptance index, and purchase intention) indicated that all treatments have similar characteristics and are good alternatives for fish consumption. However, the highest purchase

\section{References}

ANVISA. Brazilian National Health Surveillance Agency. Resolution RDC No. 12 of January 2nd, 2001. http://portal.anvisa.gov.br/legislacao

AOAC. Official methods of analysis of AOAC International (19th ed.). Gaithersburg, MD, USA, AOAC International, 2012.

Barbosa-Cánovas, G.V., Tápia, M.S., Cano, M.P. Novel Food Processing Technologies. Sous vide / Freezing Technology for Ready Meals. CRC Press, 2005.

Bligh, E.G., Dyer, W.J. A rapid method of total lipid extraction and purification. Canadian Journal of Biochemical Physiology, 1959, 37, 911-914. https://doi.org/10.1139/059-099

Can, M.F., Günlü, A., Can, H.Y. Fish consumption preferences and factors influencing it. Food Science and Technology, 2015, 35, 339-346. https://doi.org/10.1590/1678-457X.6624

Cavenaghi-Altemio, A.D., Ferreira, R., Fonseca, G.G. Evaluation of sausages obtained from mechanically separated Nile tilapia (Oreochromis niloticus) meat and prepared using different homogenizing and refining processes. Meat Technology, 2020, 61, 145152. https://doi.org/10.18485/meattech.2020.61.2.4

Cavenaghi-Altemio, A.D., Hashinokuti, A.A., Albuquerque, D.M., Fonseca, G.G.

Transglutaminase addition increases quality and acceptation of sausages obtained from mechanically separated meat of hybrid sorubins. Emirates Journal of Food and Agriculture, 2018, 30, 952-958. https://doi.org/10.9755/ejfa.2018.v30.i11.1860

Crepaldi, D.V., Faria, P.M.C., Teixeira, E.A., Ribeiro, L.P., Costa, Â.A.P., de Melo, D.C., Cintra A.P.R., Prado S.A., Costa F.A.A., Drumond M.L., Lopes V.E., de Moraes V.E. The Brazilian catfish in Brazil aquaculture. Revista Brasileira de Reprodução Animal, 2006, 30, 150-158.

Embarek, P.K.B., Huss, H.H. Heat resistance of Listeria monocytogenes in vacuum packaged pasteurized fish fillets. International Journal of Food Microbiology, 1993, 20, 85-95. intention of $97.23 \%$ for ready-made dishes prepared according to T1 (brine solution without olive oil or tomato sauce) is the best product for commercialization.

\section{Acknowledgments}

The authors are indebted to the Brazilian research funding agencies CNPq, CAPES and FUNDECT for their financial support.

Frascá-Scorvo, C.M.D., Baccarin, A.E., Vidotti, R.M., Romagosa, E., Scorvo-Filho, J.D., Ayroza, L.M.S. Influence of stoking densities, intensive and semiintensive rearing systems on carcass yield, nutritional quality of the fillet and organoleptic characteristics of pintado Pseudoplatystoma corruscans. Boletim do Instituto de Pesca, 2008, 34, 511-518. https://www.pesca.sp.gov.br/boletim/index.php/bip/a rticle/view/821

Gonçalves, A.A., Passos, M.G., Biedrzycki, A. Consumer's perception of seafood package: Case study with students of Food Engineering course. Estudos Tecnológicos, 2009, 5, 14-32. https://doi.org/10.4013/ete.2009.51.02

Honma, J.M., Rulim, C.R., Batistela, B.B., Campinas, D.L.A.L., Martelli, S.M., Cavenaghi-Altemio, A.D. Use of fishing slaughterhouse waste for the development of pasty paté. Brazilian Journal of Development, 2020, 6, 25234-25243. https://doi.org/10.34117/bjdv6n5-106

Husein, Y., Secci, G., Mancini, S., Zanoni, B., Parisi, G. Nutritional quality, physical properties and lipid stability of ready-to-cook fish products are preserved during frozen storage and oven-cooking. Journal of Aquatic Food Product Technology, 2020, 29, 207 217. https://doi.org/10.1080/10498850.2019.1708834

ISO. International Organization for Standardization. Animal and vegetable fats and oils. Preparation of methyl esters of fatty acids. Geneve: ISO. Method ISO, 5509, 1-6, 2000.

Leira, M.H., do Nascimento, A.F., Alves, F.R., Orfao, L., Lacerda, Y.G., Botelho, H.A., Reghim, L., Lago, A.A. Characterization of different techniques for obtaining minced fish from tilapia waste. Food Science and Technology, 2019, 39, 63-67. https://doi.org/10.1590/fst.37517

Lopes, I.G., de Oliveira, R.G., Ramos, F.M. Profile of fish consumption by the Brazilian population. Biota Amazônia, 2016, 6, 62-65. https://doi.org/10.18561/21795746/biotaamazonia.v6n2p62-65 
MAPA. Ministry of Agriculture, Livestock and Supply. Normative Instruction $\mathrm{N}^{\mathrm{o}}$. 6, from February 15th, 2001. https://www.gov.br/agricultura/pt-br/

Moreira, A.B., Visentainer, J.V., Souza, N.E., Matsushita, M. Fatty acids profile and cholesterol contents of three Brazilian brycon freshwater fishes. Journal of Food Composition and Analysis, 2001, 14, 565-574. https://doi.org/10.1006/jfca.2001.1025

Palmeira K.R., Mársico E.T., Monteiro M.L.G., Lemos M., Conte Junior C.A. Ready-to-eat products elaborated with mechanically separated fish meat from waste processing: challenges and chemical quality. CyTA - Journal of Food, 2016, 14, 227-238. https://doi.org/10.1080/19476337.2015.1087050

Ramos Filho, M.M., Ramos, M.I.L., Hiane, P.A., Souza, E.M.T. Lipid profile of four species of fish from the Pantanal region of Mato Grosso do Sul. Food Science and Technology, 2008, 28, 361-365. https://doi.org/10.1590/S0101-20612008000200014

Santos, L.D., Zara, R.F., Visentainer, J.V., Matsushita, M., Souza, N.E., \& Franco, M.L.R.S. Sensory evaluation and yield of tilapia (Oreochromis niloticus) smoked fillets in rosemary (Rosmarinus officinalis) presence. Ciência Agrotécnica, 2007, 31, 406-412. https://doi.org/10.1590/S141370542007000200021

Sigurgisladottir, S., Sigurdardottir, M.S., Torrissen, O., Vallet, J.L., Hafsteinsson, H., Effects of different salting and smoking processes on the microstructure, the texture and yield of Atlantic salmon (Salmo salar) fillets. Food Research International, 2000, 33, 847-855. https://doi.org/10.1016/S09639969(00)00104-6
Simopoulos, A. The importance of the ratio of omega6/omega-3 essential fatty acids. Biomedicine \& Pharmacotherapy, 2002, 56, 365-379. https://doi.org/10.1016/s0753-3322(02)00253-6

Soccol, M.C.H., Oetterer, M. Use of modified atmosphere in seafood preservation. Brazilian Archives of Biology and Technology, 2003, 46, 569580. https://doi.org/10.1590/S151689132003000400011

Stone, H.S., Sidel, J.L. Sensory Evaluation Practices, $3^{\text {rd }}$ ed. Academic Press, San Diego, 2004.

Suárez-Mahecha, H., Francisco, A., Beirão, L.H., Block, J.M., Saccol, A., Pardo-Carrasco, S. Importance of polyunsaturated fatty acids present in pond-reared and wild fish for human nutrition. Boletim do Instituto de Pesca, 2002, 28, 101-110.

USDA/FSIS. USDA/FSIS Microbiology Laboratory Guidebook. $3^{\text {rd }}$ ed. United States Department of Agriculture. Food Safety and Inspection Service, Washington, DC, 1998.

Vaudagna, S.R., Sanchez, G., Neira, M.S., Insani, E. M., Picallo, A.B., Gallinger, M.M., \& Lasta, J.A. Sous vide cooked beef muscles: Effect of low temperature-long time (LT-LT) treatments on their quality characteristics and storage stability. International Journal of Food Science and Technology, 2002, 37, 425-411. https://doi.org/10.1046/j.1365-2621.2002.00581.x 